\title{
BISCUIT FORMULATION WITH SUBSTITUTION OF BROWN RICE FLOUR
}

\author{
Slamet Widodo ${ }^{1}$, Saifuddin Sirajuddin ${ }^{2}$ \\ ${ }^{1}$ Faculty of Engineering, Universitas Negeri Makassar, \\ Makassar,90221, Indonesia \\ slamet.widodo@unm.ac.id \\ ${ }^{2}$ Faculty of Public Health,Hasanuddin Universty, \\ Makassar, 90232, Indonesia \\ slamet.widodo@unm.ac.id; saifuddin59@yahoo.com
}

\begin{abstract}
Focus of this study was formulation of biscuit with substitution of brown rice flour which was widely accepted by the community. The objective of the study was to formulate biscuit substitution by brown rice flour. The experiment was conducted in Maret-July 2017 in Family Welfare Education Laboratory. Data collected was quality of biscuit (color, flavor, texture, taste, and overall) and the preference. Data were analyzed by Mean and ANOVA. Result: $18 g$ wheat flour, $6 g$ cornstarch, $4 g$ tapioca starch, $19 \mathrm{~g}$ brown rice flour, $12 \mathrm{~g}$ margarine, $29 \mathrm{~g}$ eggs yolk, and $12 \mathrm{~g}$ refined sugar. Nutrition contents the best biscuit was water 2,52g, ash 1,19g, fat 24,46g, protein 11,68g, carbohydrate 60,15g, and energy 507,46Kcal.
\end{abstract}

KEYWORDS: Biscuit, Brown Rice Flour, Formulation

\section{INTRODUCTION}

Nutrition problem was associated with education achievement and schooling period. Malnourished children caused problem in their growth and development resulting in less educated, poor, less healthy, and more susceptible to diseases adult (Steckel, 2013). Result of the cohort study(Victora et al., 2008)concluded that small birth size and stunting was associated with low adult height, body fat mass reduction, low schooling period, impaired intellectual function, and later giving birth to low birth weight baby.

Optimization of nutrition improvement for school children was conducted through diversification of food developed formula considering nutrition aspect, health benefit, acceptance, shelf life and local food sources brown rice (Oryza nivara). The other potential source which was still limitedly used was brown rice. Brown rice contained antioxidant which can prevent various degenerative diseases. Brown rice was still limitedly consumed since the characteristic was poorer than white rice (Widodo, Riyadi, Tanziha, \& Astawan, 2015b). 
Several studies showed that antioxidant content in brown rice could be used to prevent coronary heart disease, cancer, diabetes, and hypertension as well as to treat xerophthalmia and beriberi. As additive for food and beverage, brown rice has potential to improve antioxidant in medicinal beverage of rice and herbs. In addition, brown rice isolate can produce lovastatin which is potential to reduce blood cholesterol. Brown and black rice also can clear atherosclerosis plaque and improve antioxidant status in rabbit. The production of brown rice was 0.03 million ton in 2011 and 0.05 million ton in 2012(Widodo, Riyadi, Tanziha, \& Astawan, 2015c).

Based on these facts, formulation of nutritious food using brown rice in form of biscuit was important. The strength of biscuit was small size, relatively long shelf life, and good, acceptance by the community. Manufactured biscuit was currently not enriched by local food sources with high nutrients, such as fish and brown rice.

Use of brown rice in biscuit was expected to be preferred so that the benefit was optimally obtained. Therefore, study about biscuit formulation using those three sources was very essential so that the objective of this study was to formulate biscuit with substitution of brown rice flour.

\section{METHODOLOGY}

The experiment was conducted in Maret-July 2017 in Culinary Art Laboratory of Universitas Negeri Makassar. The main ingredients in the study were wheat flour, cornstarch, tapioca starch, brown rice flour, yolk, sugar, vanilla extract, and baking powder. The tools were spoon, spatula, knife, washbowl, pan, frying pan, blender, mixer, biscuit print, flour strainer, kitchen scale and oven.Nutrient Analysis. Nutrient analysis: Nutrient analysis conducted was protein content using semi-micro Kjeldahl method, fat content using Soxhlet method, water content using direct heating method, ash content with dry ashing method, carbohydrate content using by difference (Widodo, Riyadi, Tanziha, \& Astawan, 2015a).Experimental design: Biscuit formulation with substitution of brown rice flour was conducted using completely randomized design. Acceptance test to the biscuit used 7-point hedonic quality test and 11-point hedonic organoleptic test. Data Collection and Analysis: Data collection was conducted by collecting responses to the biscuit's color, flavor, texture, taste, and overall quality from 16 trained panelists using sensory evaluation of hedonic test. The color was ranged from very light brown to very dark brown (scale 1-7), while flavor was ranged from very good to very bad (scale 1-7). The texture was evaluated with ranged of very hard to very soft (scale 1-7), while the taste was ranged from very bad to very good (scale 1-7). The overall was very bad to very good (scale 1-7), while the preference was evaluated as highly unpreferred to highly preferred (scale 1-11). Data were analyzed using Mean and ANOVA with Duncan Posthoc Test (Widodo et al., 2015a).

\section{RESULT}

\section{RESULTS AND DISCUSSION}

\subsection{Biscuit Formulation}

Biscuit subtitution by brown rice flour was expected to improve the nutrient content of the biscuit in order to help meeting energy and protein 
requirement of school children. The formulation in this study was based on difference in composition of brown rice flour.

Biscuit Making Process; The process of making biscuits starts with the preparation of biscuit making equipment such as oven, mixer, bowl, spatula. Preparation of controlled biscuit ingredients are wheat flour, margarine, egg, sugar, and vanilla. While nutritious solid biscuit ingredients are wheat flour, meizena, starch, water,freshwater fish flour, marine fish flour, brown rice flour, margarine, egg yolks, refined sugar. The manufacturing process begins with margarine, egg, sugar, for 15 minutes using a mixer, then mixed with flour. For control biscuits using wheat flour, while for nutritional biscuits using freshwater fish powder, marine fish meal, and brown rice flour. The next process is printing, then baking for 20-25 minutes and cooled The process of making biscuits can be seen in Figure1.

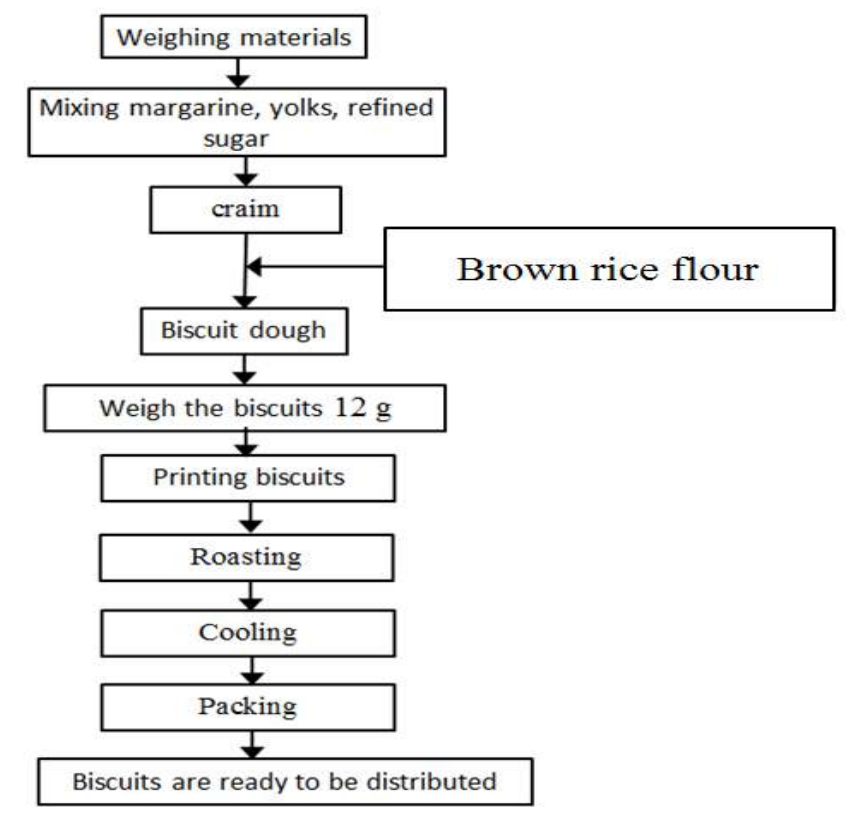

Figure 1. Making proces of biscuits in Table 1.

Biscuit formulation; The details of biscuit formulation were presented

Table 1.Formulation of biscuit subtitution by brown rice flour (100 g)

\begin{tabular}{llccccc}
\hline \multirow{2}{*}{ Komposisi bahan } & & \multicolumn{5}{c}{ Formulasi } \\
\cline { 3 - 7 } & & Fo & F31 & F32 & F33 & F34 \\
\hline Wheat Flour & gram & 30 & $\mathbf{1 8}$ & $\mathbf{1 5}$ & 12 & 9 \\
Corn flour & gram & 10 & 6 & 5 & 4 & $\mathbf{3}$ \\
Tapiocca Flour & gram & 7 & 4 & 4 & 3 & 2 \\
Brown Rice Flour & gram & 0 & 19 & 24 & 28 & 33 \\
Margarine & gram & 12 & 12 & 12 & 12 & 12 \\
Egg Yolk & gram & 29 & 29 & 29 & 29 & 29 \\
Sugar & gram & 12 & 12 & 12 & 12 & 12 \\
Total 100 gram & gram & $\mathbf{1 0 0}$ & 100 & 100 & 100 & $\mathbf{1 0 0}$ \\
\hline
\end{tabular}


Changes in the use of materials from wheat flour, cornstarch, tapioca starch. brown rice flour based on existing formulations but for margarine, yolk, and refined sugar have not changed for all formulations, this is based on calculations from the existing fomulation.

\subsection{Quality of Biscuit}

Organoleptic test of those 12 biscuit formulas and 1 control was conducted for their color, flavor, texture, taste, overall and acceptance. The details were presented in Table 2 .

Table 2. Mean score of organoleptic test of the biscuit

\begin{tabular}{lcccccc}
\hline Indicator & F0 & F31 & F32 & F33 & F34 & $\begin{array}{c}\mathrm{p} \\
\text { Value }\end{array}$ \\
\hline Color & $(4,1 \pm 0,9)^{\mathrm{ab}}$ & $(3,3 \pm 1,3)^{\mathrm{a}}$ & $(3,6 \pm 1,3)^{\mathrm{ab}}$ & $(4,3 \pm 0,8)^{\mathrm{b}}$ & $(3,7 \pm 0,9)^{\mathrm{ab}}$ & 0,124 \\
Aroma & $(4,1 \pm 0,9)^{\mathrm{a}}$ & $(4,5 \pm 1,7)^{\mathrm{a}}$ & $(4,9 \pm 1,04)^{\mathrm{a}}$ & $(3,9 \pm 1,6)^{\mathrm{a}}$ & $(5,2 \pm 1,3)^{\mathrm{a}}$ & 0,277 \\
Texture & $(4,1 \pm 0,9)^{\mathrm{a}}$ & $(4,6 \pm 1,4)^{\mathrm{a}}$ & $(4,6 \pm 1,3)^{\mathrm{a}}$ & $(4,5 \pm 1,3)^{\mathrm{a}}$ & $(4,7 \pm 1,03)^{\mathrm{a}}$ & 0,684 \\
Taste & $(4,1 \pm 0,9)^{\mathrm{a}}$ & $(4,9 \pm 1,9)^{\mathrm{a}}$ & $(5,2 \pm 1,1)^{\mathrm{a}}$ & $(4,5 \pm 1,4)^{\mathrm{a}}$ & $(5,2 \pm 1,3)^{\mathrm{a}}$ & 0,162 \\
Over all & $(4,1 \pm 0,9)^{\mathrm{a}}$ & $(4,8 \pm 1,5)^{\mathrm{ab}}$ & $(5,4 \pm 0,9)^{\mathrm{b}}$ & $(4,4 \pm 1,3)^{\mathrm{a}}$ & $(5,3 \pm 1,1)^{\mathrm{b}}$ & 0,033 \\
Acceptence & $(4,1 \pm 0,9)^{\mathrm{a}}$ & $(7,5 \pm 1,9)^{\mathrm{b}}$ & $(7,2 \pm 1,9)^{\mathrm{b}}$ & $(6,4 \pm 1,9)^{\mathrm{b}}$ & $(6,7 \pm 1,9)^{\mathrm{b}}$ & 0,000 \\
\hline
\end{tabular}

Notes: $*=p<0.05$ :significant. Similar superscript letters in one row showed no difference. Color (1-7) = very dark-very light; Flavor $(1-7)=$ very bad-very good; Texture (1-7) = very hard-very soft; Taste $(1-7)=$ very bad-very good; Overall (1-7) = very bad-very good; Acceptance (111) = highly unpreferred-highly preferred

Color test results with organoleptic tests showed dark brown biscuit color ratings and the color tended to be younger with reduced use of brown rice flour(Widodo et al., 2015a). Anova color biscuit test showed very different but based on advanced test duncans each biscuit formula is not different. The results of aroma test with organoleptic test showed the value of aroma of biscuit is not scented and rather fragrant and the aroma tends to aroma is reduced / not fragrant. This is due to the increasing of fish flour and decreasing of brown rice flour(Sharma, Das, Barooah, Alam, \& Baruah, 2017)(Anamika \& Vishakha, 2017). Anova aroma biscuit test showed very different and based on advanced test each biscuit formula. The results of taste test with organoleptic test showed the usual value-rather unpleasant tend to be uncomfortable. This is due to the decrease of flour and other flour(Sharma et al., 2017)(Anamika \& Vishakha, 2017). The Anova taste biscuit test showed very different and based on advanced test. Overall test results with organoleptic tests showed rather good not good. This leads to the decline of wheat flour and subtitution another flour(Sharma et al., 2017)(Anamika \& Vishakha, 2017). Anova flavor biscuit tests are very different and based on a follow-up trial each biscuit formula shows F31 as different from the others

\subsection{Acceptance of Biscuit}

Based on Table 2, formula F31had the highest score and. Biscuit formulated in this study was short dough with characteristic of inelastic dough (Manley, 2001)(Stefanova, Zlateva, \& Stoyanova, 2017).Overall test results with organoleptic tests showed rather good not good. This leads to the decline 
of wheat flour and substitution another flour(Sharma et al., 2017)(Anamika $\&$ Vishakha, 2017). Anova flavor biscuit tests are very different and based on a follow-up trial each biscuit formula shows F31 as different from the others.

\subsection{Nutrient Content of Biscuit}

The nutritional content of selected biscuits and control biscuits (without the substitution of brown rice flour can be seen in Table 3

Table 3. The nutritional content of selected biscuits and control biscuits

\begin{tabular}{lcrrrrr}
\hline \multicolumn{1}{c}{$\begin{array}{c}\text { Nutrition } \\
\text { Contens }\end{array}$} & & \multicolumn{1}{c}{ Fo } & \multicolumn{1}{c}{ F31 } & \multicolumn{1}{c}{ F32 } & \multicolumn{1}{c}{ F33 } & \multicolumn{1}{c}{ F34 } \\
\hline Water Content & $\mathrm{g}$ & 2.03 & 2.52 & 3.01 & 3.5 & 3.99 \\
Ash Content & $\mathrm{g}$ & 0.75 & 1.19 & 1.63 & 2.07 & 2.51 \\
Fat Content & $\mathrm{g}$ & 17.43 & 24.46 & 31.49 & 38.52 & 45.55 \\
Protein Content & $\mathrm{g}$ & 7.72 & 11.68 & 15.64 & 19.6 & 23.56 \\
Carbohydrate & $\mathrm{g}$ & 72.07 & 60.15 & 48.23 & 36.31 & 24.39 \\
Crude Fiber & $\mathrm{g}$ & 4.51 & 3.38 & 2.25 & 1.12 & -0.01 \\
Zinc, Zn & $\mathrm{mg} / \mathrm{Kg}$ & 24.77 & 21.43 & 18.09 & 14.75 & 11.41 \\
Iron, Fe & $\mathrm{mg} / \mathrm{Kg}$ & 35.5 & 32.32 & 29.14 & 25.96 & 22.78 \\
Calsium, Ca & $\mathrm{mg} / \mathrm{Kg}$ & 93.78 & 115.84 & 137.9 & 159.96 & 182.02 \\
Energi & $\mathrm{Kcal}$ & 476.03 & 507.46 & 538.89 & 570.32 & 601.75 \\
\hline
\end{tabular}

Table 3 shows changes in the nutritional content of biscuits after the substitution of brown rice flour. Such increase in protein and fat, but on carbohydrates has decreased. This can be attributed to the substitution ingredients that contain fat and protein in than wheat flour, but the carbohydrate content decreases because the content of additional material is lower than wheat flour. This is like the results of previous research by Widodo (2015) and Asmoro (2012) that with an increase in protein-containing ingredients and fatty acids will affect the protein and fat content of the resulting biscuits(Widodo et al., 2015a)(Asmoro, Kumalaningsih, \& Mulyadi, 2012)(Bhasker, 2016)(Jain, Grover, \& Gill, 2017)(Doporto, Sacco, Viña, \& García, 2017).

\section{DISCUSSION}

Color plays an important role in determining consumer acceptance because it is the first impression obtained by consumers. The color of a brown biscuit is produced due to the substitution of brown rice. Brown rice that gives the red color is due to the antioxidant content in the form of anthocyanin which gives the color brown. The brown color of brown rice is increasingly visible when the brown rice gets warmed up. The brown color is also influenced by the caramelization of the sugar in both the pure sugar present in the material and the sugar content present in the other ingredients. The color change other than the material used is also affected by the processing time. This is in line with the results of the studies of Asmoro and Neves, et al. Which suggest that the more the amount of ingredients substitution affects the color of the resulting product [12], [13].

Fragrant aroma in the resulting biscuits is the result of protein breakdown and the occurrence of sugar caramelization also gives a distinctive aroma to the biscuit. In this study the more fish meal more fragrant biscuits produced but the taste is decreasing. A similar study was also presented by Yarnpakde, et al and Valterová 
suggesting that fish flavors and flavors are in contrast, due to protein content in fish with a distinctive aroma (Yarnpakdee, Benjakul, Penjamras, \& Kristinsson, 2014),(Valterová, 2015)(Zwicky, n.d.).The texture of the biscuit is strongly influenced by the composition of the starch material used, the higher the gluten content of the flour used, causing the texture of the biscuit to become harder. For that reason the use of red rice flour can make the texture quality of biscuits better; this brown rice gluten content is very small. Similar results were also reported by Losio that excessive use of gluten-free flour causes the quality of biscuits to become crumbs, but if using gluten-high gluten flours causes the biscuits to become hard (Losio et al., 2016)(Liu, Deng, Sha, Hashem, \& Gai, 2017).

The delicious and tasty flavor of the biscuits produced is due to a combination of margarine and fat, proteins present in the main ingredients and additives. The right blend causes the taste to be savory and can eliminate the fishy taste of sardines. Substitution of sardine flour if excessive causes flavor in the biscuit is reduced / uncomfortable, this is in line with the results of research from Abdel and Selcuk stating that the substitution of fish bone meal gives a better flavor compared to that not give(Abdel-Moemin, 2015),(Nuray Erkan, Özkan Özden, 2010),(Widodo \& Sirajudin, 2017)(Han, Daniel, Amir, \& Wan, 2013). Gluten formation was minimized in the dough creation to form kneaded dough. The first stage in biscuit formulation was mixing process. The mixing process was divided into two stages, namely cream formulation and dry ingredient mixing. In the cream formulation stage, margarine was stirred in medium speed and then substitution with refined sugar. After stirred well, yolk was substitution and then stirred again at high speed. After the cream was browning, baking powder and vanilla extract were substitution (Nga et al., 2009)(Anggraini \& Putri, 2016)(Arpi \& Edward, 2016).

The next step was adding wheat flour and other flours into the cream which then stirred until kneaded. Overkneading enables gluten matrix formation. Therefore, in order to create biscuit with good quality, the stirring was done minimally (Manley, 2001)(Mohamed, Sulieman, Soliman, \& Bassiuny, 2014)(Kusumawati, Anggarani, Setiarso, \& Muslim, 2017)(Technology, 2016). The next process was weighing and printing to get similar size, which was $0.3 \mathrm{~cm}$ and $12 \mathrm{~g}$. After that, the baking process for 30 minutes with temperature of $150^{\circ} \mathrm{C}$ was conducted. Baking processmade change in texture to the preferred one, change in surface color, and reduction of moisture. The size of baked biscuit was reduced due to moisture lost during baking process. Several factors affecting the size were size of flour particle, dough creation, and use of margarine in the baking tray. After baking process, the biscuit was immediately chilled to reduce temperature and harden the product due to condensed sugar and fat (Manley, 2001)(Obasi, Uchechukwu, \& Eke-obia, 2012)(Islam \& Taneya, 2012).

The results of taste test with organoleptic test showed the usual value-rather unpleasant tend to be uncomfortable. This is due to the decrease of flour and other flour(Sharma et al., 2017)(Anamika \& Vishakha, 2017). The Anova taste biscuit test showed very different and based on advanced test each biscuit formula showed F31 different from the others. The level of favorite biscuits is strongly influenced by the level of one's habit of consuming food. The more often a person consumes the food it will form a habit of the food, thus allowing the joy of food is very large. This is in accordance with the opinion Widodo et al stated that the formation of fish food habits of the coastal community is higher than in the mountains, this is due to 
the availability of materials around more and facilitate the processing and fulfilled the needs of society (Widodo et al., 2015a).

Consumption of 10 pieces (100 grams) biscuit without the substitutionof brown rice flour daily contributed $17.8 \%$ energy and $15.5 \%$ protein from AKG (F0 / standard biscuit) and $15.5 \%$ and protein $22.8 \%$ of AKG (F79 with the substitutionbrown rice flour)([Kemenkes RI], 2013). The nutritional content of complete foods and easy to treat foods to be served the family will create a healthy family. Healthy family members, especially family members during the growth period (toddlers, school-age children, pregnant and lactating mothers, and the healing process) are in need of optimal nutrition. Fulfillment of nutritional needs well will create optimal health conditions. Optimal health will help in activities and high productivity such as learning and work, and reduce morbidity. Families with low morbidity levels will reduce the cost of treatment and transferable costs are more productive again(Aries, 2006).

Development and innovation of food consumption in society with various local materials that exist around the community itself with the aim of diversifying the pattern of food and improve the quality of food community, while also avoiding the level of community allergies to certain foods. The increasingly diverse consumption of society will improve public health(Aries, 2006)

Limitations in this study is not done research on the durability of biscuits with various packaging and it's effect on one's nutritional status.

\section{CONCLUSIONS}

The best biscuit subtitution formula for brown rice flour was formula 31 which was composed by $18 \mathrm{~g}$ wheat flour, $6 \mathrm{~g}$ cornstarch, $4 \mathrm{~g}$ tapioca starch, $19 \mathrm{~g}$ brown rice flour, $12 \mathrm{~g}$ margarine, $29 \mathrm{~g}$ yolk, and $12 \mathrm{~g}$ refined sugar. Nutrition contents the best biscuit was water $2,52 \mathrm{~g}$, ash $1,19 \mathrm{~g}$, fat $24,46 \mathrm{~g}$, protein $11,68 \mathrm{~g}$, carbohydrate $60,15 \mathrm{~g}$, and energy $507,46 \mathrm{Kcal}$.

\section{ACKNOWLEDGMENT}

We would to acknowledge Ministry of Research, Technology and Higher Education for the funding through doctoral research scheme program 2017-2018

\section{REFERENCES}

[Kemenkes RI]. (2013). Peraturan Menteri Kesehatan Republik indonesia nomor 75 tahun 2013 (Angka Kecukupan Gizi yang dianjurkan bagi Bangsa Indoneis).pdf. Jakarta.

Abdel-Moemin, A. R. (2015). Healthy cookies from cooked fish bones. Food Bioscience, 12, 114-151. https://doi.org/10.1016/j.fbio.2015.09.003

Anamika, G., \& Vishakha, S. (2017). Organoleptic Evaluation of Nutritious Biscuits. International Journal of Science, Environment and Technology, 6(1), 98-103.

Anggraini, T., \& Putri, V. J. (2016). Characteristics of Red Sweet Potato ( Ipomea batatas ) Analog Rice ( SPAR ) From The addition of Cassava Flour ( Manihot 
utillisima ) and Carrot ( Daucus carota ), 6(5), 723-728.

Aries, M. M. D. (2006). Estimasi Kerugian EkonomiAkibat Status Gizi Buruk dan Biaya. Jurnal Gizi Dan Pangan, 1(November), 26-33.

Arpi, N., \& Edward, S. (2016). Extraction and Properties of Gelatin from Spotted Oceanic Triggerfish ( Canthidermis maculata ) Skin and Bone, 6(5), 561-567.

Asmoro, L. C., Kumalaningsih, S., \& Mulyadi, A. F. (2012). Karakter Oganoleptik Biskuit dengan Penambahan Tepung Ikan Teri Nasi ( Stolephorus spp. ). Jurnal Tenologi Pertanian UB, 1-8.

Bhasker, V. (2016). Development and Evaluation of High Protein and Low Gluten Biscuits. INTERNATIONAL JOURNAL OF INNOVATIVE TECHNOLOGY AND RESEARCH, 4(4), 5329-5335.

Doporto, M. C., Sacco, F., Viña, S. Z., \& García, M. A. (2017). Quality and Technological Properties of Gluten-Free Biscuits Made with Pachyrhizus ahipa Flour as a Novel Ingredient. Food and Nutrition Sciences, 8, 70-83. https://doi.org/10.4236/fns.2017.81005

Du, P., Wu, X., Xu, J., Dong, F., Liu, X., Wei, D., \& Zheng, Y. (2017). Determination and dissipation of mesotrione and its metabolites in rice using UPLC and triple-quadrupole tandem mass spectrometry. Food Chemistry, 229, 260-267. https://doi.org/10.1016/j.foodchem.2017.02.079

Han, S., Daniel, S., Amir, W., \& Wan, N. (2013). Incorporation of dietary fibrerich oyster mushroom ( Pleurotus sajor-caju ) powder improves postprandial glycaemic response by interfering with starch granule structure and starch digestibility of biscuit.

Islam, M., \& Taneya, M. (2012). Physicochemical and Functional Properties of Brown Rice (Oryza sativa) and Wheat (Triticum aestivum) Flour and Quality of Composite Biscuit Made Thereof. A Scientific Journal of Krishi Foundation The Agriculturists, 10(November), 20-28. Retrieved from http://www.banglajol.info/index.php/AGRIC/article/view/13135

Jain, T., Grover, K., \& Gill, N. K. (2017). Impact of garden cress supplemented biscuits on nutritional profile of malnourished 1 and anemic 2 school children. Nutrition \& Food Science, 47(4). https://doi.org/10.1108/NFS-09-2016-0144

Kusumawati, N., Anggarani, M. A., Setiarso, P., \& Muslim, S. (2017). Product Standarization of Ginger ( Zingiber officinale Rosc .) and Red Ginger ( Zingiber officinale var . Rubrum ) Simplicia through Washing Time, Slice Thickness and Raw Materials Drying Process Optimization, 7(1), 15-21.

Liu, D., Deng, Y., Sha, L., Hashem, A., \& Gai, S. (2017). Impact of oral processing on texture attributes and taste perception. Journal of Food Science and Technology. https://doi.org/10.1007/s13197-017-2661-1

Losio, M. N., Dalzini, E., Pavoni, E., Merigo, D., Finazzi, G., \& Daminelli, P. (2016). A survey study on safety and microbial quality of gluten-free products made in Italian pasta factories. Food Control, 1-7. https://doi.org/10.1016/j.foodcont.2016.08.020

Manley, D. (2001). Biscuit, cracker and cookie recipes for the food industry. Woodhead Publishing Ltd and CRC Press LLC.

Mohamed, G. F., Sulieman, A. M., Soliman, N. G., \& Bassiuny, S. S. (2014). Fortification of Biscuits with Fish Protein Concentrate. World J. Dairy \& Food Sci, 9(2), 242-249. https://doi.org/10.5829/idosi.wjdfs.2014.9.2.1142

Nga, T. T., Winichagoon, P., Dijkhuizen, M. A., Khan, N. C., Wasantwisut, E., 
Furr, H., \& Wieringa, F. T. (2009). Multi-micronutrient-fortified biscuits decreased prevalence of anemia and improved micronutrient status and effectiveness of deworming in rural vietnamese school children. Journal of Nutrition, 139(5), 1013-1021. https://doi.org/10.3945/jn.108.099754

Nuray Erkan, Özkan Özden, and A. S. (2010). Effect of frying, grilling, and steaming on amino acid composition of marine fishes. Journal of Medicinal Food.

Obasi, N. E., Uchechukwu, N., \& Eke-obia, E. (2012). Production and Evaluation of Biscuits from African Yam Bean ( Sphenostylis stenocarpa) and Wheat ( Triticum aestivum ) Flours . Food Science and Quality Management, 7, 513.

Sharma, D., Das, M., Barooah, M., Alam, S., \& Baruah, D. K. (2017). Evaluation of Sensory Attributes Biscuits Developed using Single and Multiple Blend Nutraceuticals. Int. J. Pure App. Biosci, 5(2), 433-440.

Steckel, R. H. (2013). Malnutrition Global economic losses attributable to malnutrition 1900- 2000 and projections to 2050. Ohio State University: Copenhagen Consensus on Human Challenges.

Stefanova, M., Zlateva, D., \& Stoyanova, A. (2017). Impact of the Integrated Management Systems on the Achievement of Stable Quality and Safety of Biscuit Products, 7, 173-185. https://doi.org/10.17265/21595828/2017.04.001

Technology, A. (2016). The Effect of Cassava Leaf Extract Additional in Antioxidant Activity and Fe Content of Wet Noodle, 6(5), 594-599.

Valterová, I. (2015). Effect of heat treatment on the n-3 / n-6 ratio and content of polyunsaturated fatty acids in fish tissues, 176, 205-211. https://doi.org/10.1016/j.foodchem.2014.12.058

Victora, C. G., Adair, L., Fall, C., Hallal, P. C., Martorell, R., Richter, L., \& Sachdev, H. S. (2008). Maternal and child undernutrition: consequences for adult health and human capital. The Lancet, 371(9609), 340-357. https://doi.org/10.1016/S0140-6736(07)61692-4

Widodo, S., Riyadi, H., Tanziha, I., \& Astawan, M. (2015a). Acceptance Test of Blondo, Snakehead Fish Flour and Brown Rice Flour based Biscuit Formulation. International Journal of Sciences: Basic and Applied Research (IJSBAR), 4531, 264-276.

Widodo, S., Riyadi, H., Tanziha, I., \& Astawan, M. (2015b). Improving nutritional status of children under five year by the intervention of blondo, snakehead fish (Channa striata), and brown rice (Oryza nivara) based biscuit. J. Gizi Pangan, 10(2), 85-92.

Widodo, S., Riyadi, H., Tanziha, I., \& Astawan, M. (2015c). Perbaikan Status Gizi Anak Balita Dengan Intervensi. J. Gizi Pangan, 10(2), 85-92.

Widodo, S., \& Sirajudin, S. (2017). Effect of Drying Time on Quality of Mozambique Tilapia Fish (Oreochromis Mossambicus) and Round Sardinella (Sardinella Aurita) Flour. In International Conference ADRI - 5 ("Scientific Publications toward Global Competitive Higher Education”) (pp. 157-163). Makassar.

Yarnpakdee, S., Benjakul, S., Penjamras, P., \& Kristinsson, H. G. (2014). Chemical compositions and muddy flavour / odour of protein hydrolysate from Nile tilapia and broadhead catfish mince and protein isolate, 142, 210-216. 
https://doi.org/10.1016/j.foodchem.2013.07.043

Zwicky, F. (n.d.). Physical Characteristics, Chemical Composition, Organoleptic Test And The Number Of Microbes In The Biscuits With Addition Of Flour Banana Peels. https://doi.org/10.1088/1742-6596/755/1/011001 